\title{
Reforming Science, Mathematics, and Technology Education: NSF's State Systemic Initiatives
}

University of Pennsylvania

Follow this and additional works at: https://repository.upenn.edu/cpre_policybriefs

Part of the Educational Assessment, Evaluation, and Research Commons, and the Science and Mathematics Education Commons

\section{Recommended Citation}

University of Pennsylvania. (1994). Reforming Science, Mathematics, and Technology Education: NSF's State Systemic Initiatives. CPRE Policy Briefs.

Retrieved from https://repository.upenn.edu/cpre_policybriefs/69

This publication was a work of the Consortium for Policy Research in Education.

View on the CPRE website.

This paper is posted at ScholarlyCommons. https://repository.upenn.edu/cpre_policybriefs/69

For more information, please contact repository@pobox.upenn.edu. 


\title{
Reforming Science, Mathematics, and Technology Education: NSF's State Systemic Initiatives
}

\author{
Abstract \\ This brief presents some initial observations about the Statewide Systemic Initiatives based on the first \\ two years of an evaluation study, and discusses some of the issues state and local leaders faced as they \\ attempted to transform science, mathematics, and technology education (1994). \\ Disciplines \\ Educational Assessment, Evaluation, and Research | Science and Mathematics Education \\ Comments \\ This publication was a work of the Consortium for Policy Research in Education. \\ View on the CPRE website.
}




\section{Reforming Science, Mathematics, and Technology Education: NSF's State Systemic Initiatives}

Since 1991, the National Science Foundation (NSF) has signed cooperative agreements with 26 states to undertake ambitious and comprehensive initiatives to reform science, mathematics, and technology education. This important effort to improve public education is known as the Statewide Systemic Initiatives Program, or the SSI.

Following a competitive application process, NSF made five-year awards of up to ten million dollars to each participating state. The states funded in 1991, 1992, and 1993 are displayed in Figure 1. Two companion NSF programs, the Urban and Rural Systemic Initiatives (USI and RSI), will support similar reforms in the nation's largest cities and poorest rural areas. The first round of USI is shown in Figure 1.

In order to assess the results of the investment in the SSI, NSF contracted with SRI International and its partners, the Consortium for Policy Research in Education, Policy Studies Associates, and the Council of Chief State School Officers to conduct a national evaluation of the SSI program. This brief presents some initial observations about the SSIs based on the first two years of the evaluation study, and discusses some of the issues state and local leaders are facing as they attempt to transform science, mathematics, and technology education. ${ }^{\prime}$

\section{The Challenge}

There is a consensus among business leaders, academicians, and policymakers that higher levels of literacy in science, mathematics, and technology are essential to the future economic growth of the United States. Peter Drucker forecasts that knowledge workers will make up more than a third of the nation's workforce by the end of the century. Knowledge, he contends, is becoming the key national resource, and the quality of schools will be an increasingly critical factor in international economic competition. ${ }^{2}$ Drucker and many observers contend that the United States must improve the quality of its education system in order to be competitive in this changing environment.

International assessments of student performance in mathematics and science have found that students in the United States are not performing as well as students in European and Pacific Rim countries. In the most recent comparative study, the second International Assessment of Educational Progress (IAEP) administered in 1991, American 13 year-olds were outperformed by students from Korea, Switzerland, and Taiwan in all areas of mathematics, and by students in Hungary, Korea, and Taiwan in three out of four areas of science. ${ }^{3}$ While some analysts such as Gerald Bracey dispute these findings, contending that the differences in student achievement on the IAEP across nations are small and that re-analysis shows American students out-performing their Asian counterparts in some instances, the consensus of opinion is that American students are lagging behind in mathematics and science. ${ }^{4}$

Equally disturbing are the gaps in mathematics and science achievement between majority and minority students and between males and females within the 


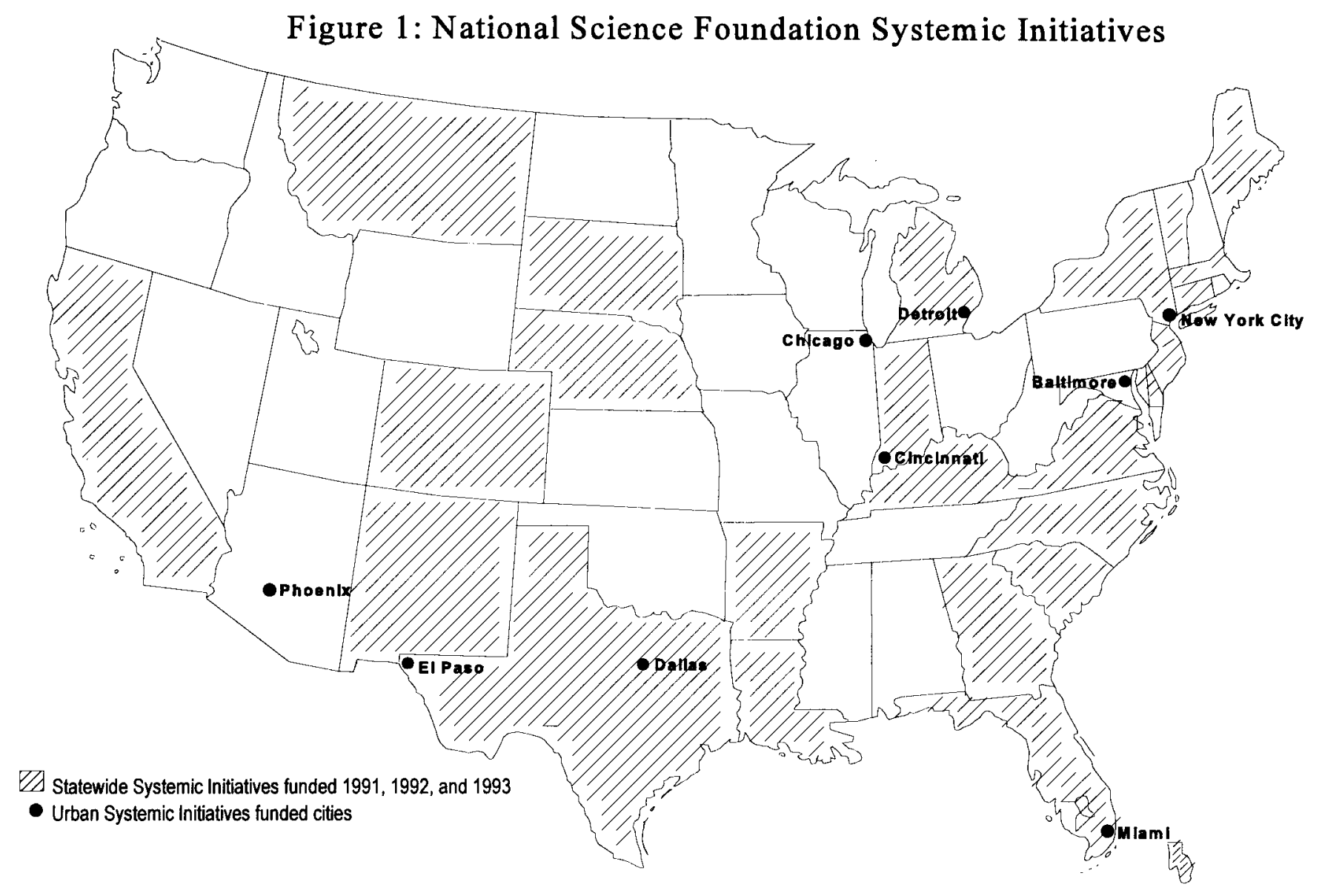

United States. For example, data from the National Assessment of Educational Progress (NAEP) show that only 37 percent of Hispanic students and only 26 percent of African-American students were at or above the basic proficiency level in mathematics, compared to 73 percent of white students. Enrollments in high school mathematics and science courses and participation in Advanced Placement programs show similar disparities. ${ }^{5}$ There are also gender gaps in mathematics and science attainment. The 1990 and 1992 NAEP results show similar proficiency levels in science and mathematics for boys and girls in grade four, but performance gaps appear in science in grade eight and in mathematics in grade $12 .{ }^{6}$ However, gender gaps in participation in advanced mathematics and science courses in high school and in Advanced Placement participation are being reduced.?

What accounts for the inadequate performance of American public school students in mathematics and science? Surveys of teachers and administrators indicate that substantial numbers of American children have not been receiving the kind of instruction recommended by mathematics and science educators, that many public school teachers have not received adequate preparation in mathematics and science, that standards and expectations have been too low, (especially for female and minority students), that schools have under-invested in science facilities and equipment, and that mathematics and science have not been priorities in the schools.
There are also significant environmental obstacles to improving student performance. For example, while American 13 year-olds are more likely to have access to computers, they spend less time doing mathematics and science homework and more time watching television than their peers in most other developed countries. ${ }^{8}$ The incentives for students to work harder and learn more in math and science are not strong, as American colleges and universities tend to send weak signals about the importance of high achievement in math and science, and employers of high school graduates often pay little attention to their academic performance.

\section{NSF's Response}

The National Science Foundation has responded to this national 
problem by challenging the states to undertake comprehensive reforms in mathematics, science, and technology education. The SSI program is a significant departure from past practice at NSF in several ways: (1) the funding is for a longer term and is larger in amount; (2) NSF is taking a more activist role, seeking to leverage state and private funds and promote the coordination of programs within states; and (3) the initiative has a stronger policy orientation than most previous NSF programs. By asking the states to mobilize broad-based coalitions to undertake ambitious reforms in mathematics and science education, NSF is attempting to serve as a strategic broker, bringing together those who have identified problems with those who have the resources and skills to help solve them.

\section{What is Systemic Reform?}

NSF's strategy reflects the views of many education policymakers and scholars who believe that meaningful reforms in schools are most likely to be achieved through state initiatives that set clear and ambitious learning goals and standards, align all of the available policy levers in support of reform, stimulate school-level initiatives, and mobilize human and fiscal resources to support these changes. This approach is now widely referred to as systemic reform.

Two critical premises underlie systemic reform: (1) all children can meet significantly higher standards if they are asked to do so, and given adequate opportunities to master the content; and (2) state and local policy changes can create these opportunities by giving schools strong and consistent signals about the changes in practice and performance that are expected. While the specifics may vary somewhat from state to state, systemic reform initiatives generally include:

- efforts to develop professional and public support for higher standards, and for the reforms needed to help all students reach them;

- the adoption of ambitious, common goals for student learning;

- setting challenging academic standards for all students, and developing more rigorous curricula and assessment procedures reflecting those standards;

- aligning state and local policies (finance, curriculum, student assessment, teacher preparation and professional development, college admissions, and social service delivery) in support of the goals and standards;

- increased collaboration and resource-sharing among the agencies, institutions, and groups concerned with public education; and

- expanded opportunities for teachers to enhance their knowledge of subject matter content and to acquire, practice, and critique new approaches to curriculum, pedagogy, and assessment.

\section{State Visions of Good Practice}

Most SSI states began their initiatives by establishing clear goals for what students should know and be able to do in mathematics and science. Table 1 displays examples of these state goals. They are quite similar across the states as a consequence of recent national dialogues about goals and standards. The standards developed by the National Council of Teachers of Mathematics (NCTM) and the proposed science standards developed by the $\mathrm{Na}$ tional Research Council of the National Academy of Science, the American Association for the Advancement of Science, and the National Science Teachers Association have provided critical guidance to the SSIs. ${ }^{9}$

However, emergence of a national consensus about broad standards does not mean that policymakers, educators, mathematicians, and scientists in each state will reach exactly the same conclusions about what children should learn, how they should learn it, or even what efforts are needed to put the necessary changes in place. For example, Montana's vision of improved teaching and learning incorporates the use of technology to a much greater extent than most other SSI states. Vermont has committed itself to integrating the teaching and learning of mathematics and science to a much greater degree than other states. These and similar differences across the states reflect variations in demographics, geography, resources, values, and educational structure. They also offer opportunities to gain greater understanding about the effectiveness of various approaches to school reform.

\section{State Strategies for Implementing Ambitious Goals}

What are the SSIs doing to help teachers put the new visions of teaching and learning into practice? The SSIs' strategies for change reflect their states' reform histories and political traditions. The strategies appropriate for California, with its history of wellaligned reform initiatives and strong state leadership, differ from 
those used in South Dakota with its quite different history and traditions. Table 2 shows how the states differ in their strategic focus. The primary strategies for changing practice are providing professional development and funding local initiatives and model schools. Other important strategies include: aligning state policies, building new infrastructures, reforming higher education, and mobilizing public and professional opinion in support of reform are important support strategies. Each of these six strategies will be discussed below.

\section{Teacher Professional Development}

Collectively, the SSIs reported providing professional development to more than 50,000 teachers during the past year, or approximately 8 percent of the public school teachers in the participating states. The number of teachers participating varies by grade level and subject matter; states report reaching more than 1 in every 5 middle school mathematics teachers, but only 1 in every 20 high school mathematics teachers.

The logic of focusing SSI resources on teacher professional development is straightforward; changing practice means changing the skills, knowledge, and beliefs of classroom teachers. The challenge lies in developing a strategy that provides on-going, in-depth professional development while reaching a significant portion of those who teach mathematics and science. One approach is to use lead teachers. Virginia, for example, holds summer institutes for lead teachers and asks school administrators to provide them with small budgets and release time to model lessons and provide training for their colleagues. The goal is to leverage the training of these 500 lead teachers by having them train hundreds more of their colleagues. Kentucky's Partnership for Reform Initiatives in Science and Math (PRISM) has

\section{Table 1: Selected Excerpts from SSI Vision Statements}

Florida. "Students successfully compete at the highest levels nationally and internationally and are prepared to make well-reasoned, thoughtful, and healthy lifelong decisions."

Georgia. "[The Georgia SSI aims to produce students who are] creative problem solvers, critical thinkers, questioners, experimenters, innovators, effective communicators, and reflective learners."

New York. "To implement world-class learning outcomes and new and more authentic assessments in mathematics, science and technology in research and development schools."

North Carolina. "[Students need to] develop an appreciation for and disposition to use mathematics and science in evaluating and solving problems."

Vermont. "The SSI vision in Vermont is to transform science, math and technology education by dramatically increasing the science and mathematics skills of all Vermont students to very high standards and to ensure the ability of all Vermonters to pursue scientific and technical careers."

provided intensive professional development for mathematics, science, and technical "specialists." These specialists, with the support of university faculty, are expected to become the base for regional networks of teachers that will stimulate and support classroom reforms. The specialists are also expected to provide technical assistance, conduct professional development programs, and develop innovative curricular materials.

California has formed teacher networks for elementary science and middle school mathematics. Each network has a director and approximately 10 full-time teacher consultants who oversee all activities and serve as resources in each region of the state. In the science component, each participating school sends a lead teacher to a summer institute and follow-up sessions during the year. The lead teacher in turn is given release time to provide 25 hours of inservice to the entire elementary school staff with the assistance of a specialist. In the math component, middle school teachers are prepared through summer institutes and follow-up workshops during the school year. The goal of both components is to develop networks of teachers who can support efforts to devise and implement more effective approaches to the teaching of mathematics and science.

All of the SSI states, regardless of their primary strategy, are addressing professional development needs. For example, as Puerto Rico introduces a new curriculum into its schools, the SSI is providing teachers with assistance in implementing it. New York and Delaware are providing professional development for administrators and teachers in their model schools. In Michigan, SSIsponsored experts work directly 
Table 2: SSI Strategies for Promoting Systemic Reform

\begin{tabular}{|c|c|c|c|c|c|c|c|c|}
\hline State & $\begin{array}{l}\text { Aligning } \\
\text { State } \\
\text { Policy }\end{array}$ & $\begin{array}{c}\text { Supporting } \\
\text { Teacher } \\
\text { Professional } \\
\text { Development }\end{array}$ & $\begin{array}{l}\text { Creating an } \\
\text { Infrastructure for } \\
\text { Capacity } \\
\text { Building }\end{array}$ & $\begin{array}{c}\text { Developing \& } \\
\text { Disseminating } \\
\text { New Content \& } \\
\text { Materials }\end{array}$ & $\begin{array}{l}\text { Funding Local } \\
\text { Systemic } \\
\text { Initiatives }\end{array}$ & $\begin{array}{l}\text { Supporting } \\
\text { Model } \\
\text { Schools }\end{array}$ & $\begin{array}{l}\text { Reforming Higher } \\
\text { Education \& } \\
\text { Teacher } \\
\text { Preparation }\end{array}$ & $\begin{array}{l}\text { Mobilizing } \\
\text { Public \& } \\
\text { Professional } \\
\text { Support }\end{array}$ \\
\hline AR & & $P$ & $P$ & & & & & \\
\hline $\mathrm{CA}$ & & $P$ & & & & & & \\
\hline $\mathrm{CO}$ & & & $S$ & & $P$ & & $S$ & $S$ \\
\hline CT & & & $S$ & & $P$ & & $S$ & $\mathrm{P}$ \\
\hline$D E$ & & & & & & $P$ & & \\
\hline$F L$ & & $P$ & & & & $P$ & & $S$ \\
\hline$\overline{G A}$ & & & & & & & $P$ & \\
\hline $\mathrm{KY}$ & & $P$ & $P$ & & & $P$ & $S$ & $S$ \\
\hline$L A$ & & $P$ & & & & & $S$ & $\mathrm{~S}$ \\
\hline MA & & & & & $P$ & & $S$ & $S$ \\
\hline $\mathrm{ME}$ & $S$ & $P$ & $S$ & & $P$ & & $S$ & \\
\hline $\mathrm{MI}$ & $S$ & & $P$ & & $P$ & & $S$ & \\
\hline MT & $S$ & $S$ & & $P$ & & & & \\
\hline $\mathrm{NC}$ & & $P$ & $S$ & & & & & \\
\hline $\mathrm{NE}$ & & $P$ & $P$ & $\mathrm{P}$ & $S$ & & & \\
\hline $\mathrm{NJ}$ & & $S$ & $P$ & & $P$ & & & \\
\hline NM & & $P$ & $P$ & $S$ & & & $S$ & \\
\hline NY & $S$ & & & & $S$ & $P$ & & \\
\hline $\mathrm{OH}$ & & $P$ & $P$ & & & & $S$ & $S$ \\
\hline PR & & $P$ & $s$ & $P$ & & $P$ & $S$ & \\
\hline $\mathrm{SC}$ & $S$ & $P$ & $P$ & & & & & $S$ \\
\hline SD & & & & & $P$ & & & \\
\hline$T X$ & $S$ & & $P$ & & & & & \\
\hline $\mathrm{VA}$ & & $P$ & & & & & $P$ & $S$ \\
\hline$V T$ & $S$ & $\mathrm{P}$ & $S$ & & $S$ & & & \\
\hline
\end{tabular}

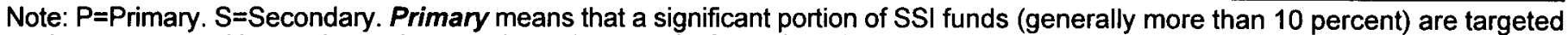
on the strategy and it constitutes the core thrust (or one of a few) of the SSI. Secondary means that it is a key portion of the strategy, but is not central.

with professional development providers to improve their services and ensure that subsequent professional development efforts are aligned with the goals and visions of the SSI.

\section{Building Capacity to Extend and Sustain Reforms}

Most states' strategies include building statewide capacity for professional development beyond the opportunities sponsored directly by the SSIs. Such strategies explicitly recognize three factors: (1) the SSIs do not have the resources to reach all teachers in most states; (2) the SSIs' funding will eventually run out; and (3) the need for professional development will be ongoing. The three states mentioned above-Virginia, Kentucky, and California-are attempting to build such capacity. So are states like Arkansas, North Carolina, Ohio, and South Carolina, where regional centers are meant to serve the ongoing professional development needs of teachers.

Another capacity-building strategy involves the use of technology to support teachers' efforts to change their practice. Nebraska, for example, is investing in satellitetransmitted distance learning, including the use of interactive video for both the training of teachers and the teaching of students. Nebraska and other states are linking teachers through state computer networks in order to promote teacher-to-teacher communication and increase teachers' access to instructional resources. Kentucky is making curriculum units developed by its science and math specialists available over its computer network. Connecticut is providing information about effective programs, grants, and 
professional development opportunities to teachers over its network.

Finally, new non-governmental organizations are playing key leadership roles in some states. While the majority of the SSIs are led by state education agencies, organizations "external" to the bureaucratic hierarchy are taking leadership roles in some states. Some of these, like the Kentucky Science and Technology Council and the Montana Council of Teachers of Mathematics, are not new organizations, but they are taking on new responsibilities. Others, such as the Council for the Advancement of Mathematics and Science Education in New Mexico and the Connecticut Academy for Education in Science, Mathematics, and Technology are new entities. These non-governmental organizations are of particular interest because of their potential to build broad-based, bipartisan support that can sustain the SSI vision and its activities across electoral cycles.

\section{Supporting Local Initiatives and Model Sites}

Some SSIs are granting funds to local districts to design their own reform initiatives. For example, Michigan has awarded competitive grants of up to $\$ 65,000$ to 11 target districts. Connecticut has made three-year awards to 19 districts. In both instances districts are expected to design local initiatives to improve mathematics and science instruction. Massachusetts, South Dakota, New Jersey, and Vermont are among the other states providing grants to local districts. This strategy allows for considerable variation across districts and moves responsibility for development to the local level.
A few states by-pass districts altogether to target schools. One approach is to support model schools. This approach devotes a relatively large amount of resources to a small number of schools on the premise that they will serve as "existence proofs," demonstrating that the reforms are feasible and effective, and that others will learn from, and follow, their example. In Delaware, where the SSI is part of a comprehensive reform known as "New Directions," the SSI funds and supports a network of 17 schools. Under cooperative agreements with the state, these schools are developing curriculum and assessment strategies that will help students meet the state's high learning standards. They are also serving as models for other schools.

New York has taken a similar approach, focusing its efforts on a relatively small number of schools (11 across the entire state, all located in six urban centers). These schools are intended to be research and development sites in which school organization is restructured, performance assessments are used, new approaches to teaching and learning are employed, and professional development is established as an ongoing activity. If successful, they will demonstrate that it is possible to offer a world-class education within an inner-city setting.

\section{State Policy Alignment}

One of the central tenets of systemic reform is that the myriad of public policies governing the educational enterprise-from teacher credentialing to student assessment to textbook adoption-should be aligned with the new goals and standards. In general, however, the alignment of state policies has not been a

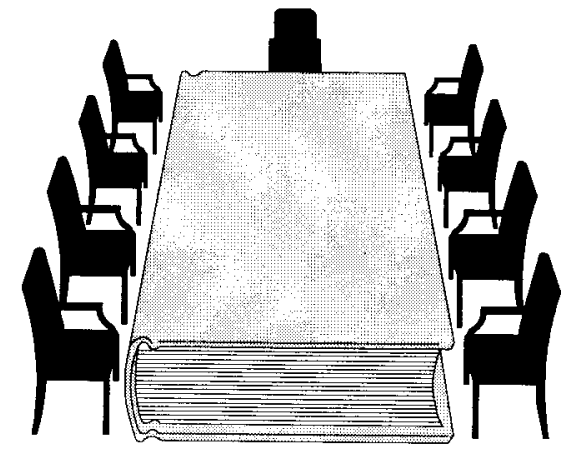

central strategy for most SSI initiatives. One reason is that in a number of states, the policy system is already aligned with the SSI goals. In Kentucky and California, for example, state learning goals, curricular frameworks, and assessment policies are aligned with one another and consistent with the goals of the SSI. In these cases, the SSIs can be viewed as supporting implementation of visions developed as part of preexisting systemic reform efforts.

In a number of other states, the SSIs are supporting the development of new and better aligned state policies. For example, in Connecticut, Delaware, Georgia, Massachusetts, New Jersey, New Mexico, Puerto Rico, and Vermont, the SSIs are supporting the development of new curriculum frameworks in mathematics and science. The SSIs are also contributing to revisions of teacher licensure policies in several states.

In a some states, however, the revision of state policies is simply not considered a fruitful strategyat least not as a first step in the reform agenda. Most often this is due to strong traditions of local control, as in Nebraska and South Dakota, where it seems to make little political sense to push for more state action to direct or guide schools. However, even in states with strong traditions of local control, SSIs have sought changes in state policies that were particularly important to their 
success. For example, the Montana SSI is replacing traditional high school mathematics with an integrated and ambitious curriculum. In order to make it easier for districts and schools to adopt these new materials, the Montana SSI persuaded the state's public universities to change their admissions policies to provide full credit for students studying the new curriculum.

\section{Reforming Higher Education and the Preparation of Teachers}

Some SSIs are working to improve the preparation of teachers. A common approach has been for the SSI to issue a Request for Proposal to institutions of higher education (IHEs) to design and implement innovative pre-service education programs. Both Virginia (three IHEs) and Puerto Rico (five IHEs) are following this model. Virginia's SSI is also supporting the redesign of the introductory mathematics and science courses in their universities. Puerto Rico has added a transition program that matches new teachers with mentors, and includes additional training in content, pedagogy, and classroom management. Georgia's SSI includes a number of university-based projects targeting undergraduate preparation of future teachers of mathematics and science. For example, the SSI is funding the University of Georgia at Athens to develop a set of principles to guide teacher education and teacher credentialing.

Connecticut has asked the IHEs to work collaboratively with school districts to create new pre-service programs that meet the needs of the schools. Public school teachers and university faculty are working together to design and teach undergraduate courses in mathematics and science that are consistent with the SSI's vision of good practice. This emphasis on collaboration between schools and institutions of higher education is also found in Massachusetts and Colorado.

\section{Mobilization of Public and Professional Opinion}

Most SSIs have recognized the importance of building professional and public support for their reform agendas. This requires public relations skills not readily available within the mathematics and science communities. As one SSI policymaker noted, "[w]e knew from the beginning that the key would be public support and we knew that educators were terrible at selling their product, and so we needed professional help."

Some SSIs have reached out to the business community and the media for assistance. For example, Connecticut has launched an ambitious campaign to build public and professional support. The campaign uses $\mathrm{TV}$, radio, newspapers, events, speakers, and takehome materials. All five television stations in the state as well as the only statewide newspaper are participating. Small weeklies and shoppers are being distributed in ethnic communities. The object is to have messages about the importance of mathematics and science and the SSI's vision of reform appear as frequently as possible in different media. And, the SSI staff are providing assistance to urban districts trying to build local support for reform.

\section{Putting the Pieces Together: Systemic Reform}

Each of these component strategies of the SSIs is important. The question is whether, in a given state, the SSI strategies taken in combination with other state reform initiatives form a coherent, comprehensive strategy for improving public education. Louisiana's School Improvement Initiative (LaSIP) is a good example of an SSI that is addressing all of the critical elements of the system. The SSI team in Louisiana has extended its reach through a partnership with the state department of education, matching funds from the state treasury, and collaboration with a number of externally funded reform initiatives. As a result, LaSIP staff are involved in improving professional development (through competitive grants to collaboratives), drafting new curriculum frameworks (through an Eisenhower grant), developing new assessment items for use by teachers, revamping pre-service teacher education (through another cooperative agreement with NSF), reexamining teacher certification requirements (along with the state department staff), and exploring the use of technology in education. LaSIP is demonstrating the potential of leveraging limited NSF dollars through collaboration.

Kentucky is another example of a comprehensive approach to reform. The central strategy of Kentucky's SSI, PRISM, is increasing capacity to support improvements in mathematics, science, and technology education through the creation of regional networks of specialists. In addition, PRISM has funded model schools, developed curricular units and performance assessment tasks, supported improvements in pre-service educa- 
ledge of pedagogy and subject matter and overcome teacher beliefs about science and mathematics that obstruct reform. Professional development also must be intense, continuous, and closely connected to practice.

While new structures, such as teacher networks and collaboratives between schools and universities, hold great promise, little progress has been made in changing state policies affecting recertification, compensation, or allocation of instructional time. Such policies affect teachers' professional development decisions and their participation on a continuing basis.

Finally, there is the daunting problem of "scaling up." How can the SSIs leverage their limited resources into a capacity to change practice in all schools and classrooms rather than just a few? In large states like California, Flori$\mathrm{da}$, Ohio, and Texas, the initiatives must reach many more schools than in less populated states such as Delaware, Montana, South Dakota, and Vermont.

The large states have selected strategies that build regional capacity such as model sites, turnkey training, and networks, and are planning to reach their schools in phases. The smaller states are trying to reach their schools more

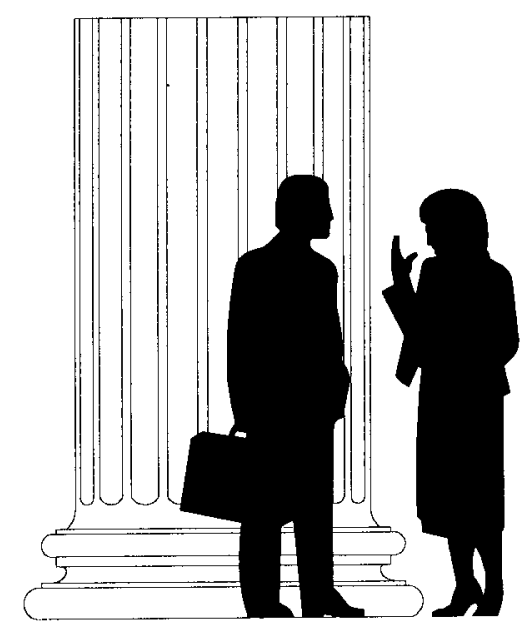

quickly, and have selected strategies that promote broad teacher participation in development. As a consequence of this tension between resources and scale, many SSIs are now visible only in pilot sites or only at certain grade levels. A key challenge facing the SSIs is moving out from these modest beginnings to other schools, a task that has stymied other attempts at school reform.

\section{The Agenda for State Policymakers}

Beyond the strategic problems that confront the SSIs lie more political issues. These issues must be addressed by state policymakers if the reforms stimulated by NSF are to be sustained. Perhaps the most significant of these issues is the lack of public understanding of the reforms. There is ample evidence that many parents and citizens simply do not understand and/or believe in the basic premise undergirding standards-based reform: that all children can learn to much higher levels. Nor do many citizens see the need to focus more time and attention on science and higher-order mathematics. In fact, the majority appear to believe that basic skills are sufficient for most students. State policymakers must open a sustained dialogue with the public about the rationale for school reform. While heeding public concerns and being responsive, they must try to persuade them that the status quo in public education is not good enough for their children.

A second political issue is the need for greater policy alignment and stability. To succeed, the SSIs are trying to forge new links between $\mathrm{K}-12$ education and higher education to improve teacher training and professional development in mathematics and science. They are working with state policymakers to develop and maintain policy alignment in curriculum, assessment, and school accreditation. They are attempting to achieve these objectives in an unstable climate in which priorities are changing and competition for limited state resources is increasing. They must build lasting coalitions of educators, business leaders, and civic leaders to create bi-partisan support for the provision of high quality mathematics and science education to all children.

A third political issue concerns timelines and expectations. The leaders of the SSIs must persuade policymakers to provide them with the time needed for the reforms to be successful. The instructional reforms the SSIs are advocating require time to implement, and once in place, additional time to produce results. Elected officials often focus on the short-term, and they can be impatient about results. If they hear too many complaints from parents or teachers about new policies and practices, and see little evidence of improvement, they may waver in their support for reform. There is no ready solution to this conflict between the long-run agendas of school reformers and the short-run needs of legislators, but better understanding of what to expect, what to look for, and regular reporting on progress may help.

\section{Conclusion: Persistence and Patience}

The good news is that changes are taking place in mathematics and science education. Many classrooms have already been affected by the work of the SSIs, and new institutions, partnerships and relationships are helping expand these gains. However, the reformers have not yet achieved the 
degree of public understanding and support that is needed to secure commitments from local and state policymakers to sustain these initiatives. Therefore, the reforms remain fragile and vulnerable in most states.

The SSIs are addressing a critical national problem, and their success or failure holds significant implications for the future quality of life in the United States. Those who are concerned about the quality of public education and who share Drucker's view of its increasing importance should offer their support to these initiatives. The SSIs need critical friends who will offer them constructive criticism where warranted, but also help sustain their efforts. NSF has set reform in motion, but its success depends on the commitment, wisdom, energy, and persistence of leaders in the states who are determined to change public education for the better.

\section{Endnotes}

1. This brief summarizes findings reported in Evaluation of NSF's Statewide Systemic Initiatives (SSI) Program: First-Year Report by Patrick Shields, Thomas Corcoran, Andrew Zucker and Associates (Washington DC: National Science Foundation, June 1994)

2. "The Age of Social Transformation," Atlantic Monthly, November 1994, 53-80.

3. The National Goals Panel, The National Education Goals Report: Building a Nation of Learners, 1994 (Washington, DC: U.S.G.P.O., 1994), 38-40.

4. Gerald Bracey. "The Third Bracey Report on the Condition of Public Education," Phi Delta Kappan, 75 (2), November 1993, 104-117.

5. See Rolf K. Blank and Doreen Gruebel, State Indicators of Science and Mathematics Education 1993 (Washington, DC: Council of Chief State School Officers, 1993).

6. Ibid., 10-11.

7. Ibid., 12.

8. Ibid.

9. See National Council for Teachers of Mathematics, Curriculum and Evaluation Standards for School Mathematics, (Reston, VA: author, 1989.); National Research Council, National Science Standards. (Washington, DC: author, 1994); National Science Teachers Association, Scope, Sequence, and Coordination of Secondary Science, Vol. I, the Content Core, (Washington, DC: author, 1993); American Association for the Advancement of Science, Benchmarks for Science Literacy, (New York: Oxford University Press, 1993).

10. For in-depth discussion of challenges policymakers face in designing and implementing systemic reform, see Susan Fuhrman, "Challenges in Systemic Education Reform," CPRE Policy Briefs, (New Brunswick, NJ: Rutgers University, Consortium For Policy Research in Education, September 1994).

11. See Judith Warren Little, "Teachers' Professional Development and Education Reform," CPRE Policy Briefs, (New Brunswick, NJ: Rutgers University, Consortium for Policy Research in Education, 1993).

\section{Related Publications from CPRE}

\section{Opportunity to Learn: Instructional Practices in Eighth-Grade Mathematics \\ Margaret E. Goertz \\ October 1994 (RR-032), 28 pp., $\$ 10.00$}

This report uses data from the 1990 National Assessment of Educational Progress (NAEP) Trial State Assessment to describe educational opportunities for students in eighth-grade mathematics in 1990 . It presents preliminary analysis of the distribution of these opportunities across the state. Specifically, the report addresses two questions: What kinds of instructional practices and curricular emphases were used in different states to teach eighth-grade math in 1990? and How and to what extent were differences in instructional practice and curricular emphases related to state characteristics and policies, such as level of spending, demographics and socioeconomic characteristics, and state curriculum and testing machines?

\section{Reform of High School Mathematics and Science and Opportunity to Learn \\ Andrew Porter and Associates}

(No. RB-13-9/94)

This policy brief concerns the nature of the high school mathematics and science curriculum in the United States. It draws from a large-scale study which documented actual instructional practices and content (the enacted curriculum) using novel methodologies. This research approach is a promising step toward the development of indicators of opportunity to learn. The study also provides encouraging news about the effect of increased standards in math and science-they did not result in a watering down of the curriculum. However, practice in the schools studied is a far cry from the ambitious goals for math and science instruction now being developed by the profession. 